from the
arehives 



\title{
All That Remains of an Angel
}

\author{
Zdeněk Kožmín
}

I borrowed the title from a book of poetry by Jan Skácel (SKÁCEL 1960), because it is not just a random set of words; it captures a major problem of both contemporary philosophy and poetry. What has, indeed, become of all those great forms of human endeavour? In his inspiring paper called "Political Socratism" (Un Socratisme Politique), Jean-Loup Thébaud provides a summary of Paul Ricoeur's text called "The Death of Personalism and the Return of a Person" (Meurt le personnalisme, revient la personne, RICOEUR 1983), where the situation in philosophy at the time is described in three points: 1 . The subject has been deprived of its place in the universe. 2 . The subject has lost a star that would guide it. 3. A clear distinction between friend and foe has disappeared (THÉBAUD 1988). While reading Patočka, Ricoeur confirms his belief that distinguishing between ontology, ethics and politics has become problematic, for the traditional trio of disciplines carries very little meaning these days, while getting dissolved in a common medium of problematization.

In July 1945, right after the war had ended, I started attending Patočka's lectures on Socrates and Plato. A great number of important philosophical questions were answered back then, but today I am much more aware that these answers were nothing but background for something much more far-reaching: a form of questioning that attempts to go deeper and further. In Patočka's discourse, arising somewhere from the depths of his Socratic reflections, there seemed to be a fascinating stream of some sort of emerging knowledge; however, it tended to lurk in the shadows and one could only get so close to it, or stay nearby. There were two aspects to Patočka's questioning - the awareness of the night and of death - both amplified by the experience of war. This is evident from the whole further development of Patočka's philosophy; however, even at the very beginning, his inquiries were into the essence of things. This 
essence cannot be reached through a simple explanation, and therefore, one may not approach it using simple questions, either. Ricoeur understood very well that Patočka's questioning overreaches into politics. It was clear from every text regarding politics that Patočka wrote after 1945. He was suspicious of simplistic questions and equally elementary, off-the-bat answers. Instead, he would use a Socratic perspective to try and approach the truth of humanity. It wasn't easy to express, for its very essence stayed in the shadows for the most part; it had to be lured out into the light. Just like Ricoeur today, we would ask back then, somewhat unconsciously - does political Socratism stand a chance? And, in a similarly subconscious manner, we wished that it did. However, Patočka was aware of the risks of political Socratism, which is both enthusiastically liberating and tragic at the same time.

Problematization was extremely relevant to Patočka, on a human level; it is provided by the material situation itself. He poses a key question:

And, ultimately, is there not at the very core of reality itself something like the mysterious and the mystery? Is mystery necessarily something subjectively private while actually it means such clarity that it can outshine all that seems clear in our everyday life? Is not the infinite depth of reality possible only because we cannot see its bottom, and is not just that a challenge and an opportunity for humans in their reach for meaning which is more than the flowering and perishing of the lily of the field in the eyes of the gods? (PATOČKA 1996: 75).

Thébaud's discourse now brings to the forefront a framework of meanings which are related to ancient Greek tragedy, namely Oresteia and her perception of horror. According to him, the ideas mentioned are the same ones that were put forward by Socrates, namely "la possibilité d'une ontologie qui ne voit pas l'être au bout du non-être, mais l'être sur fond de non-être" (THÉBAUD 1988: 87). ${ }^{1}$ And thus non-being is not a final projection, but rather a basis on which being is founded. The issue of "nothingness" carries a positive aspect in the genre of the tragedy: nothingness has potential, because it allows us to understand being in its meaning. It seems that questioning itself, which Patočka accentuates, is akin to the artistic width of scope as well as to a depth of insight. Actually, questioning alienates us from the already acquired knowledge and is in harmony with human nature:

1) “[T]he possibility of an ontology, which do not perceive being at the end of non-being but being on the background of non-being". 
Thus there is something about the human way of being that humans find estrangement somehow "more pleasant", or "more natural" than their own being. Being themselves is something that "comes naturally." It is always an achievement. In a sense, we can say that even self-estrangement is in the last instance an achievement. It is a "relief," not a "natural" lightness but the result of a certain "act" (PATOČKA 1996: 97-98).

Let us get inspired by Thébaud's journey into the realm of tragedy, in order to have a better understanding of "estrangement", and let us explore, for the same reasons but with a different form of affinity, Vladimír Holan's poetry. Holan's work is very similar to Patočka's questioning, as he constantly explores hidden, evasive meanings. Holan is a mythogenous poet; he aims to relate objects to one another, in a general sense. Connecting anything that is contradictory is Holan's mythogenous obsession; however, he gradually realizes that connecting contradictions is increasingly more difficult, that the world is somehow internally disconnected, although it may seem paradoxical in the context of a world that is becoming unified. The harder it is to establish real connections, the greater is the tension in the extremes. Holan aims to preserve the continuity of meaning in his modern mythogenesis by setting into motion the whole scope of human culture that seeks connections. He routinely molds together the Christian culture with cultures of the antiquity. Here, an abyss seeks an abyss. His poems from the years 1972-1977, titled “Goodbye?" ("Sbohem?"), from a collection named The Abyss of an Abyss (Propast propasti), allude to the concept of questioning in the very title. Let us illustrate this with a poem called "What Now?" ("Tak co?"), in which meaning is condensed into four lines:

\section{Life as a cruel game? \\ Or perhaps, could it be \\ that it's irony, \\ which overwhelms destiny?}

Život jako krutá hra?

Nebo by bylo spiše možné,

že by to byla ironie,

která je silnější než osud? (HOLAN 1982: 387)

Questioning begins by setting a starting point - what is the nature of our lives and ourselves. There are no introductions, we are placed in medias res right from 
the beginning. The first line is actually a banal question, which we sometimes ask ourselves, in a seemingly lighthearted way - isn't life just playing really weird games with us, in a cruel and completely haphazard way? Aren't we just dragged about by an unknown force, whithout any knowledge of the rules that guide it? In all that's hidden from us, are we only able to recognize cruelty? Or, is it that the guiding force of life is merely irony, with no predefined aim or purpose? Human destiny is usually understood as something predefined - it is thought to be written somewhere, in an unknown darkness, but it will come crushing upon us with sheer force, in decisive moments of our lives. However, irony is much more unpredictable, and its force would have to be of such magnitude as to be able to change destiny. Therefore, we would be much worse off with irony than with destiny itself. However, at the same time, irony is, when compared to fate, something almost maliciously creative. It is formed as if ad hoc, on the side, without being any more merciful than the old fate itself. It's most likely the other way round. Irony is probably something haphazard, something that makes witty remarks about our lives, "educates" us in a cruel way while being "self-serving". There is another poem named "What Now?" (“Tak co?”):

\author{
You were never there! \\ Yet the cause of all this, \\ not worse than with disgust \\ but gradually, revealed \\ that you will have to - \\ not without danger, of course - \\ either draw up horoscopes \\ or measure the Great Wall of China...
}

Nikdy jsi tam nebyl!

Ale př́čina toho všeho

o nic hůre než s odporem,

byt pozvolna, dávala najevo,

že ne bez nebezpečí

musís bud' sestavovat horoskopy,

nebo měrit Čínskou zed’... (HOLAN 1982: 422)

Here, irony creates two absurd alternatives: drawing up horoscopes and measuring the Great Wall of China. Neither of the two is destiny as we understand 
it; they are a sort of Sisyphean punishment, a damnation to nothingness - even though both activities retain an air of importance and grandeur, albeit ironically. The first one echoes a sense of the carnivalesque, while the second one, written in a Kafkian vein, resounds with terrifying futility.

It is possible to claim that in his poems from the 1970s, Holan further developed his ability to create tension between permanent, often latent dialogization and reaching into the void. Using Derrida's deconstruction, it may be said of many of the poems from The Abyss of an Abyss that they create a deconstructing text, which offers deconstruction as one form of the ongoing mythogenesis. In Derrida's Of Spirit. Heidegger and the Question, he accentuates Heidegger's idea that "Das Ungedachte ist sein höchstes Geschenk, das ein Denken zu vergeben hat." ("The Unthought is the highest gift that a thought can give", English translation according to DERRIDA 1989: 13). If the Unthought (das Ungedachte) is applied to philosophy, then in literature, it may be transformed into the Unsettled (das Ungedichtete). And thus, a surprising but perfectly logical parallel reveals itself: neither Holan nor Patočka offer us "clarity" in their texts; the meanings they pass on are structured more like questions about gaps in meaning. If we were to say that Patočka's Heretical Essays shifted the understandable towards the very boundaries of the phenomenal world, Holan's late poetry takes its questioning about the last existing patches of solid ground where we can still encounter meaning, and shifts it towards the very boundaries of the existence of poetry. What kinds of texts were, then, written by Patočka in the last period of his life, and what about Holan? Both of these analysts of the present situation may be called postmodern, but not necessarily. They are simply here, faced with a reality that defies both philosophy and poetry. Trying to capture a world that is constituted in this way (I'd prefer to avoid the word "structured") means producing philosophical ideas and poetry in an unknown territory where meaning is seriously, radically endangered. Patočka and Holan produced very similar texts in 1970s totalitarian Prague. However - and this is characteristic of their work - they could not share that closeness. It was a situation different from that of ancient Oresteia. Reality had to be accepted as a void into which one threw endless questions. If the questioning managed to explore a hidden meaning, it signifies both Holan's and Patočka's greatness. In this situation, the night was accepted as a peculiar certainty - a firm conviction that within the futility of existence, there must be something amidst the suddenly emerging little islands of meaning that will signify a continuity in the meaning of philosophy, as well as continuity in the meaning of poetry. In some sense, we may speak not only 
$\sim$

about Patočka's Socratism, but also about Holan's Socratism in his questioning. And, to say that for these two great solitary minds, Socratism always meant political Socratism, a fight to the death against a decadent totalitarian regime that is a claim which is almost self-evident. And therefore - if we ask once again, what is it, that remains of an angel: hasn't the angel remained almost intact?

Translated by Matouš Hořínek

\section{PRIMARY AND SECONDARY SOURCES:}

\section{DERRIDA, Jacques}

1989 [1987] Of Spirit. Heidegger and the Question, trans. Geoffrey Bennington and Rachel Bowlby (Chicago and London: The University of Chicago Press)

\section{HOLAN, Vladimír}

1982 [1972-1977] “Sbohem?”, in Vladimír Holan: Propast propasti, ed. Vladimír Justl (Prague: Odeon), pp. 261-457

\section{PATOČKA, Jan}

1996 [1990] Heretical Essays in the Philosophy of History, trans. Erazim Kohák, ed. James Dodd (Chicago and La Salle: Open Court)

RICOEUR, Paul

1983 “Meurt le personnalisme, revient la Personne”, Esprit, No. 73 (1), Janvier, pp. 113-119

SKÁCEL, Jan

1960 Co zbylo z anděla (Prague: Československý spisovatel)

THÉBAUD, Jean-Loup

1988 “Un socratisme politique”, Esprit, No. 140-141 (7-8), Juillet, pp. 76-87 


\section{COMMENTARY:}

"All that remains of an angel" was originally a lecture delivered by Kožmín at the French-Czech Summer University organized by the Jan Hus Foundation in Valtice in July 1994. The translation is based on the version that was published in Zdeněk Kožmín: Studie a kritiky (Prague: Torst 1995), pp. 550-554. For a more detailed account of Patočka's philosophy and its influence on Zdeněk Kožmín, see pp. 92-95 in this issue. 